\title{
Front Matter: Volume 8057
}

, "Front Matter: Volume 8057," Proc. SPIE 8057, Quantum Information and Computation IX, 805701 (22 June 2011); doi: 10.1117/12.901750

SDIE Event: SPIE Defense, Security, and Sensing, 2011, Orlando, Florida, United SPIE. States 


\section{PROCEEDINGS OF SPIE}

\section{Quantum Information and Computation IX}

Eric Donkor

Andrew R. Pirich

Howard E. Brandt

Editors

28-29 April 2011

Orlando, Florida, United States

Sponsored and Published by

SPIE

Volume 8057

Proceedings of SPIE, 0277-786X, v. 8057 
The papers included in this volume were part of the technical conference cited on the cover and title page. Papers were selected and subject to review by the editors and conference program committee. Some conference presentations may not be available for publication. The papers published in these proceedings reflect the work and thoughts of the authors and are published herein as submitted. The publisher is not responsible for the validity of the information or for any outcomes resulting from reliance thereon.

Please use the following format to cite material from this book:

Author(s), "Title of Paper," in Quantum Information and Computation IX, edited by Eric Donkor, Andrew R. Pirich, Howard E. Brandt, Proceedings of SPIE Vol. 8057 (SPIE, Bellingham, WA, 2011) Article CID Number.

ISSN 0277-786X

ISBN 9780819486318

Published by

SPIE

P.O. Box 10, Bellingham, Washington 98227-0010 USA

Telephone +1 3606763290 (Pacific Time) · Fax +1 3606471445

SPIE.org

Copyright (C) 2011, Society of Photo-Optical Instrumentation Engineers

Copying of material in this book for internal or personal use, or for the internal or personal use of specific clients, beyond the fair use provisions granted by the U.S. Copyright Law is authorized by SPIE subject to payment of copying fees. The Transactional Reporting Service base fee for this volume is $\$ 18.00$ per article (or portion thereof), which should be paid directly to the Copyright Clearance Center (CCC), 222 Rosewood Drive, Danvers, MA 01923. Payment may also be made electronically through CCC Online at copyright.com. Other copying for republication, resale, advertising or promotion, or any form of systematic or multiple reproduction of any material in this book is prohibited except with permission in writing from the publisher. The CCC fee code is 0277-786X/11/ \$18.00.

Printed in the United States of America.

Publication of record for individual papers is online in the SPIE Digital Library.

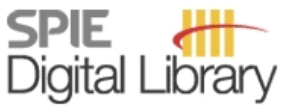

SPIEDigitalLibrary.org

Paper Numbering: Proceedings of SPIE follow an e-First publication model, with papers published first online and then in print and on CD-ROM. Papers are published as they are submitted and meet publication criteria. A unique, consistent, permanent citation identifier (CID) number is assigned to each article at the time of the first publication. Utilization of CIDs allows articles to be fully citable as soon as they are published online, and connects the same identifier to all online, print, and electronic versions of the publication. SPIE uses a six-digit CID article numbering system in which:

- The first four digits correspond to the SPIE volume number.

- The last two digits indicate publication order within the volume using a Base 36 numbering system employing both numerals and letters. These two-number sets start with 00, 01, 02, 03, 04, $05,06,07,08,09,0 A, 0 B \ldots 0 Z$, followed by 10-1Z, 20-2Z, etc.

The CID number appears on each page of the manuscript. The complete citation is used on the first page, and an abbreviated version on subsequent pages. Numbers in the index correspond to the last two digits of the six-digit CID number. 


\section{Contents}

vii Conference Committee

\section{SESSION 1 INVITED SESSION}

805702 Quantizing braids and other mathematical structures: the general quantization procedure (Invited Paper) [8057-01]

S. J. Lomonaco, Univ. of Maryland, Baltimore County (United States); L. H. Kauffman, Univ. of Illinois at Chicago (United States)

\section{SESSION 2 QUANTUM STATES AND QUANTUM LOGIC}

805703 Bright photon pair source with high spectral and spatial purity [8057-02]

J. C. Schaake, Univ. of Tennessee (United States) and Oak Ridge National Lab. (United States); R. S. Bennink, P. G. Evans, W. P. Grice, T. S. Humble, Oak Ridge National Lab. (United States)

805704 Computational model of single-photon near-field emission [8057-03]

S. Tafur, M. N. Levenberger, Univ. of Central Florida (United States)

805705 Multipli-entangled photon spontaneous parametric down-conversion source [8057-04] M. L. Fanto, R. K. Erdmann, P. M. Alsing, C. J. Peters, Air Force Research Lab. (United States); E. J. Galvez, Colgate Univ. (United States)

805706 Preparing photon pairs entangled in any desired spatial modes via interference [8057-05] E. J. Galvez, Colgate Univ. (United States)

$805707 \quad$ Experimental limits on local realism with separable and entangled photons [8057-06] R. K. Erdmann, M. L. Fanto, P. M. Alsing, C. J. Peters, Air Force Research Lab. (United States); E. J. Galvez, Colgate Univ. (United States); W. A. Miller, Florida Atlantic Univ. (United States)

\section{SESSION 3 QUANTUM IMAGING AND QUANTUM MEMORY}

805708 Generation and detection of quantum entangled states for quantum imaging [8057-07] J. F. Smith III, U.S. Naval Research Lab. (United States)

805709 Resolution enhancement of imaging systems by quantum phase amplification [8057-08] Y. C. Yin, D. French, I. Jovanovic, Pennsylvania State Univ. (United States)

8057 OA All-optical flip-flop memory for quantum computing [8057-09] E. Donkor, Univ. of Connecticut (United States) 
8057 OC Quantum computing in a piece of glass [8057-27]

W. A. Miller, Florida Atlantic Univ. (United States); P. M. Alsing, Air Force Research Lab. (United States); G. Kreymerman, Florida Atlantic Univ. (United States); J. R. McDonald, Air Force Research Lab. (United States); C. Tison, Florida Atlantic Univ. (United States)

8057 OD Logical zeros for the seven-qubit quantum error correction code [8057-12]

G. Gilbert, Y. S. Weinstein, MITRE Corp. (United States)

8057 OE Unitary quantum lattice gas representation of 2D quantum turbulence [8057-13]

B. Zhang, G. Vahala, The College of William \& Mary (United States); L. Vahala, Old Dominion Univ. (United States); M. Soe, Rogers State Univ. (United States)

8057 OF Using computer algebra in quantum computation and quantum games [8057-15]

D. A. Bolívar, Univ. EAFIT (Colombia)

SESSION 5 QUANTUM GAME THEORY, CRYPTOGRAPHY, AND MEASUREMENTS

8057 0G Causal connectivity at warp speed [8057-16]

H. E. Brandt, U.S. Army Research Lab. (United States)

8057 Ol A statistical and comparative study of quantum walks under weak measurements and weak values regimes [8057-18]

D. Ghoshal, George Mason Univ. (United States); M. Lanzagorta, ITT Advanced Engineering \& Sciences (United States); S. E. Venegas-Andraca, Tecnologico de Monterrey (Mexico)

8057 0J Quantum spread spectrum communication [8057-19]

T. S. Humble, Oak Ridge National Lab. (United States)

8057 OK Nash equilibrium in quantum superpositions [8057-20]

F. S. Khan, S. J. D. Phoenix, Khalifa Univ. of Science, Technology and Research (United Arab Emirates)

8057 OL Implementing an optical CNOT using spatial parity qubits [8057-21]

K. Kagalwala, CREOL, The College of Optics \& Photonics, Univ. of Central Florida (United States); G. Di Giuseppe, CREOL, The College of Optics \& Photonics, Univ. of Central Florida (United States) and Univ. degli Studi di Camerino (Italy); A. F. Abouraddy, B. E. A. Saleh, CREOL, The College of Optics \& Photonics, Univ. of Central Florida (United States)

8057 OM Quantum cellular automata without quiescent states [8057-22]

R. J. Irwin, H. A. Blair, Syracuse Univ. (United States)

8057 ON Rhythms essential to logical communication [8057-23]

J. M. Myers, Harvard Univ. (United States); F. H. Madjid, Consultant (United States)

805700 Quantum computing with induced dipole-dipole forbidden transitions [8057-24]

E. Donkor, Univ. of Connecticut (United States) 
8057 OP A theoretical model of multi-agent quantum computing [8057-25]

F. M. Mihelic, Light Consulting (United States)

$80570 Q$ Encoding qubits into the spatial distribution of single photons and entangled photon pairs [8057-26]

A. F. Abouraddy, B. E. A. Saleh, CREOL, The College of Optics \& Photonics, Univ. of Central Florida (United States)

8057 OR Grover's search algorithm with an entangled database state [8057-11]

P. M. Alsing, N. McDonald, Air Force Research Lab. (United States)

\section{SESSION 7 QUANTUM INFORMATION THEORY}

8057 OT Quantizing knots, groups and graphs [8057-29]

L. H. Kauffman, Univ. of Illinois at Chicago (United States); S. J. Lomonaco, Jr., Univ. of Maryland, Baltimore County (United States)

8057 OU Possible universal quantum algorithms for generalized Turaev-Viro invariants [8057-30] M. Vélez, J. Ospina, Univ. EAFIT (Colombia)

8057 OW Two-spectral Yang-Baxter operators in topological quantum computation [8057-32] W. F. Sanchez, Univ. EAFIT (Colombia)

8057 OX New gauge fields from extension of parallel transport of vector spaces to underlying scalar fields (Invited Paper) [8057-33]

P. Benioff, Argonne National Lab. (United States)

Author Index 
Downloaded From: https://www.spiedigitallibrary.org/conference-proceedings-of-spie on 26 Apr 2023

Terms of Use: https://www.spiedigitallibrary.org/terms-of-use 


\title{
Conference Committee
}

\author{
Symposium Chair
}

William Jeffrey, HRL Laboratories, LLC (United States)

Symposium Cochair

Kevin P. Meiners, Office of the Secretary of Defense (United States)

Conference Chairs

Eric Donkor, University of Connecticut (United States)

Andrew R. Pirich, ACP Consulting (United States)

Howard E. Brandt, U.S. Army Research Laboratory (United States)

Program Committee

Paul M. Alsing, Air Force Research Laboratory (United States)

Reinhard K. Erdmann, Air Force Research Laboratory (United States)

Michael R. Frey, Bucknell University (United States)

Michael J. Hayduk, Air Force Research Laboratory (United States)

Louis H. Kauffman, University of Illinois at Chicago (United States)

Vladimir E. Korepin, Stony Brook University (United States)

Samuel J. Lomonaco, Jr., University of Maryland, Baltimore County (United States)

John M. Myers, Harvard University (United States)

Alexander V. Sergienko, Boston University (United States)

Tai Tsun Wu, Harvard University (United States)

\section{Session Chairs}

1 Invited Session

Howard E. Brandt, U.S. Army Research Laboratory (United States)

2 Quantum States and Quantum Logic

John M. Myers, Harvard University (United States)

Louis H. Kauffman, University of Illinois at Chicago (United States)

Howard E. Brandt, U.S. Army Research Laboratory (United States)

3 Quantum Imaging and Quantum Memory

Reinhard K. Erdmann, Air Force Research Laboratory (United States) 
Quantum Algorithms

Samuel J. Lomonaco, Jr., University of Maryland, Baltimore County (United States)

Michael J. Hayduk, Air Force Research Laboratory (United States)

5 Quantum Game Theory, Cryptography, and Measurements

Eric Donkor, University of Connecticut (United States)

Michael L. Fanto, Air Force Research Laboratory (United States)

$6 \quad$ Quantum Computing

Samuel J. Lomonaco, Jr., University of Maryland, Baltimore County (United States)

Louis H. Kauffman, University of Illinois at Chicago (United States)

7 Quantum Information Theory

Howard E. Brandt, U.S. Army Research Laboratory (United States)

John M. Myers, Harvard University (United States) 